\title{
Development and evaluation of an immunochromatographic strip test based on the recombinant UL51 protein for detecting antibody against duck enteritis virus
}

\author{
Chanjuan Shen ${ }^{1}$, Anchun Cheng ${ }^{1,2,3^{*}}$, Mingshu Wang ${ }^{1,2,3^{*}}$, Kunfeng Sun ${ }^{1}$, Renyong Jia ${ }^{2}$, Tao Sun ${ }^{1}$, Na Zhang ${ }^{1}$, \\ Dekang Zhu' ${ }^{1,2}$, Qihui Luo ${ }^{2}$, Yi Zhou' ${ }^{2}$, Xiaoyue Chen ${ }^{1,2,3}$
}

\begin{abstract}
Background: Duck enteritis virus (DEV) infection causes substantial economic losses to the worldwide duckproducing areas. The monitoring of DEV-specific antibodies is a key to evaluate the effect of DEV vaccine and develop rational immunization programs. Thus, in this study, an immunochromatographic strip (ICS) test was developed for detecting DEV serum antibodies.

Results: The ICS test is based on membrane chromatography, and uses both the purified recombinant UL51 protein conjugated with colloidal gold and goat anti-rabbit lgG conjugated with colloidal gold as tracers, the purified recombinant UL51 protein as the capture reagent at the test line, and rabbit lgG as the capture reagent at the control line. The specificity of the ICS was evaluated by sera against DEV, Duck hepatitis virus (DHV), Riemerella anatipestifer (RA), Duck E. coli, Muscovy duck parvovirus (MPV), or Duck Influenza viruses (DIV). Only sera against DEV showed the strong positive results. In order to determine the sensitivity of the ICS, anti-DEV serum diluted serially was tested, and the minimum detection limit of 1:128 was obtained. The ICS components, which are provided in a sealed package, require no refrigeration and are stable for 12 months. To evaluate the effect of the ICS, 110 duck serum samples collected from several non-immune duck flocks were simultaneously tested by the ICS test, enzyme-linked immunosorbent assay (ELISA) and neutralization test (NT). The results showed that the sensitivity of the ICS test was almost consistent with ELISA and much higher than NT, has low cost, and is rapid (15 $\mathrm{min}$ ) and easy to perform with no requirement of specialized equipment, reagent or technicians.
\end{abstract}

Conclusions: In this work, we successfully developed a simple and rapid ICS test for detecting DEV serum antibodies for the first time. The ICS test was high specific and sensitive for the rapid detection of anti-DEV antibodies, and has great potential to be used for the serological surveillance of DEV infection in the field.

\section{Background}

Duck viral enteritis (DVE) is an acute contagious disease of various types of waterfowl (ducks, geese, and swans) caused by duck enteritis virus (DEV), which is a member of the subfamily Alpha-herpesviridae [1]. The disease affects waterfowl of all ages. Cases of the disease were recorded in domestic ducks in Holland as early as 1923 [2]. In China, the first outbreak of DVE was in

\footnotetext{
*Correspondence: chenganchun@vip.163.com; mshwang@163.com 'Avian Diseases Research Center, College of Veterinary Medicine of Sichuan Agricultural University, Ya'an, Sichuan, 625014, China

Full list of author information is available at the end of the article
}

1957 [3]. To date, only a serotype of DEV has been characterized. In duck-producing areas of the world where the disease has been reported, DVE has resulted in significant economic losses in domestic and wild waterfowls due to high mortality, condemnations and decreased egg production [1]. Several studies have indicated that DVE is difficult to monitor and control, because DEV establishes an asymptomatic carrier state in both farmed and wild waterfowl and it is only detectable during the intermittent shedding period of the virus $[1,4]$. 
Vaccination has been used as a preventive measure and also for controlling DVE disease outbreaks. Clinical and laboratory tests have confirmed that the attenuated DEV vaccine is an effective biological agents for the prevention and control of DVE, and the monitoring of DEV-specific antibodies is a key to evaluate the effect of the attenuated DEV vaccine and develop the rational immunization programs $[5,6]$. Rapid and simple test is needed for routine field practice to monitor whether the vaccines have induced antibody to DEV. Generally, the detection of anti-DEV antibodies in the serum samples of ducks usually relies on conventional techniques, such as the neutralization test (NT) $[7,8]$, enzyme-linked immunosorbent assay (ELISA) [9-11], agar gel diffusion test, Dot-ELISA assay, and passive hemagglutination assay [12]. However, the time consuming process, requiring special instrumentations and professional skills would inevitably inhibit these immunoassay techniques from benefiting the poultry farms in field applications. In contrast with these immunoassay methods, immunochromatographic strip (ICS) tests combine chromatography technology with conventional immunoassay to offer an economic, simple and rapid approach for protein analysis and clinical diagnosis, which is especially suitable for a wide variety of field applications even without the use of instruments $[13,14]$. It has been widely used as an in-field diagnosis tool to detect antibodies $[15,16]$ or antigens $[17,18]$.

The DEV UL51 protein, a conserved tegument protein, is one of 78 putative proteins encoded by the genome of DEV [19-21], and may be involved in virion maturation, similar to other alpha-herpesviruses UL51 proteins described previously [22-24]. Thus, in the present study, based on a recombinant DEV UL51 protein [19], we developed an ICS test for the field detection of DEV serum antibody, and compared the new assay with standard diagnostic tests, ELISA and NT.

\section{Results}

\section{Preparation and purification of the recombinant UL51 protein}

By the fermenter cultivation, a large number of bacterial cells containing the recombinant UL51 protein were harvest. The recombinant protein obtained was analyzed by SDS-PAGE and western blotting. Coomassie blue staining showed that the UL51 fusion protein was expressed with a molecular mass of approximately 34 $\mathrm{kDa}$ (Figure 1a). Western blotting using positive rabbit anti-DEV antiserum as the first antibody demonstrated that the recombinant UL51 protein reacted strongly and specifically with the antiserum raised against DEV (Figure 1b), suggesting that the purified recombinant UL51 protein was suitable as the capture reagent of the ICS.

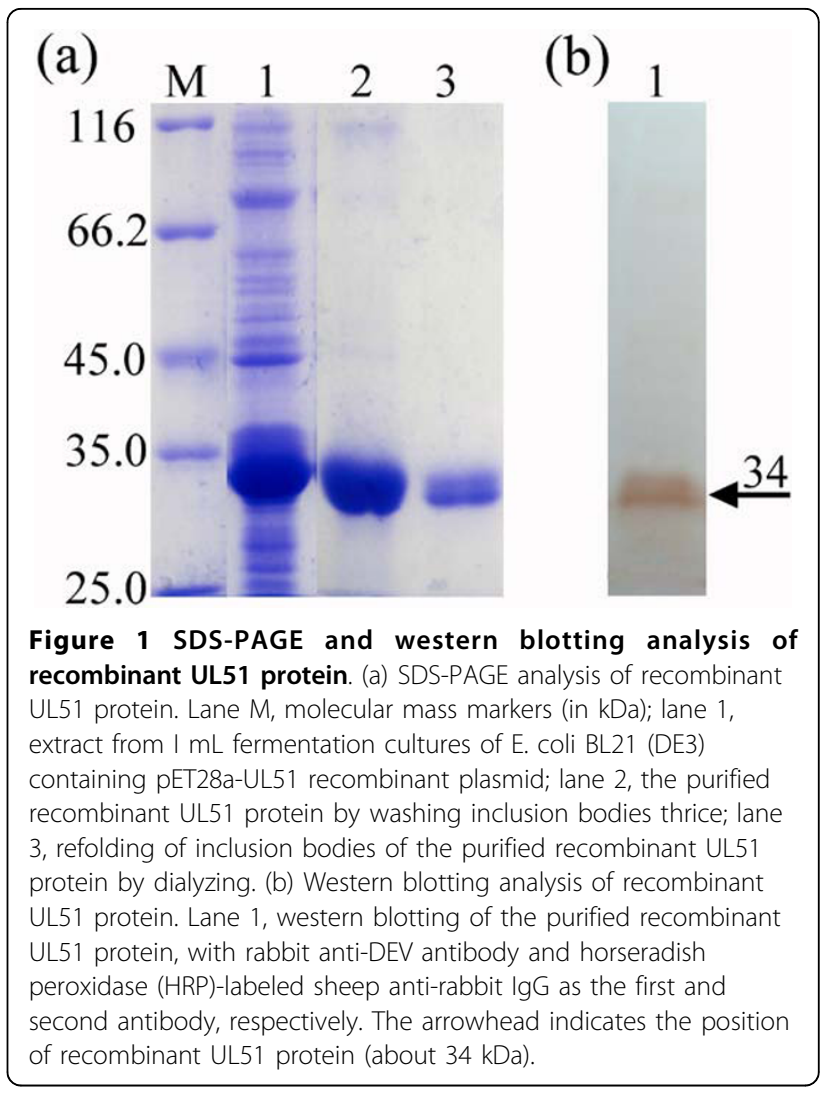

Specificity, sensitivity and stability of the ICS test

All of the 5 healthy ducks serum samples and 25 standard serum samples positive for other non-DEV pathogens were found negative for anti-DEV antibodies with the ICS test (Figure 2). The results were similar with the blank control which had only one red band at control line (Figure 2). Two bands are seen when 5 standard serum samples positive for DEV was tested (Figure 2). Similar result patterns were reproduced in repeat experiments (data not shown).

The sensitivity of the ICS was tested with anti-DEV serum diluted serially. Two red bands developed at the test line and control line with a highest dilution of 1:128 (Figure 3). The same results were repeated for 3 times with different personnel. This indicates that the ICS test has a high sensitivity for detecting small amount of anti-DEV antibodies.

With strips being respectively stored for $3,6,9$, and 12 months at room temperature (about $25^{\circ} \mathrm{C}$ ), all test results were the same from 3 to 12 months, with all known DEV-positive sera being positive and all known DEV-negative sera being negative. False positives were not detected (data not shown).

\section{Comparison with ELISA and NT}

The high sensitivity of the ICS test was also evidenced from the analysis of 110 field serum samples (Table 1). Among the 110 serum samples, 41 samples (37.27\%) were positively determined by ICS tests; the percentage 


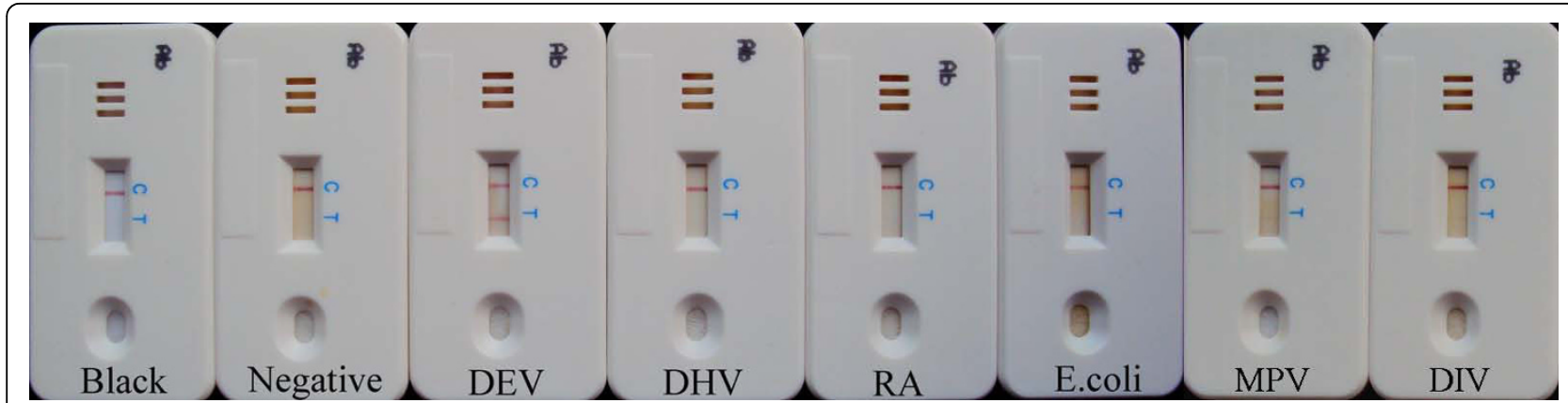

Figure 2 Specificity of the immunochromatographic strip (ICS) test. The positive sera against Duck enteritis virus (DEV), Duck hepatitis virus (DHV), Riemerella anatipestifer (RA), Duck E. coli, Muscovy duck parvovirus (MPV), or Duck Influenza viruses (DIV), and sera from healthy ducks were simultaneously tested by the ICS. Similar result patterns were reproduced in repeat experiments (data not shown).

of positive sera was comparable to the rate of $42.73 \%$ analyzed by the highly sensitive ELISA $(P \geq 0.05)$, and was notably higher than the $22.73 \%$ characterized by NT $(\mathrm{P} \leq 0.05)$. Further analyses revealed that 35 of 41 positive sera samples determined by ICS tests were also positively analyzed by ELISA, while 57 of 69 negative sera were negatively confirmed by ELISA. The ratio of positive and negative consistency for the two methods was 85.37 and $82.61 \%$, respectively (Table 2 ), with no significant difference in terms of sensitivity between the methods. Compared with NT, 8 of 41 positive sera determined by ICS tests were positively characterized by NT and 52 of 69 negative sera analyzed by ICS tests failed to show positive in NT assays (Table 2). Notably, while very few NT-positive sera were overlooked by ICS tests, many ICS-positive sera, which were confirmed by ELISA, were missed by NT. This suggests that the sensitivity of the ICS test was almost consistent with ELISA and much higher than NT. Importantly, the detection of anti-DEV IgG using the ICS test only took about 15 min; the same serum required a couple of hours with the ELISA assay and more than 3 days with NT.

\section{Discussion}

As far as we know, the antigen and a specific antibody to it are the two most important components of any serologically diagnostic assay. Generally, because the complex construction of the purified virus may incorporate various host cell proteins, antibodies against expressed protein produced during an immune reaction are more specific than those against purified virus [25]. Moreover, our studies showed that large quantities of recombinant DEV UL51 protein can be produced by large-scale fermentation and purified quickly, but the whole DEV virus cannot be easily produced and purified [26]. Furthermore, in the recent years, ICS test based on a certain recombinant protein $[13,15,27]$, has been widely used for detecting the corresponding anti-virus antibodies. So, the recombinant DEV UL51 protein described in this study, which may be substituted for the whole DEV virus, will no doubt be suitable for ongoing use in the ICS as described above, and will have widespread application in both diagnostic and research work.

In the past few decades, various classical serological methods have been used for detecting antibodies against DEV. The ELISA, which is considered currently the commercial standard for detecting antibody to DEV, uses the purified DEV virions as coating antigen, and is sensitive and specific to antibody against DEV, according to the described previously $[10,9]$. It can detect large quantities of serum samples with a high sensitivity;

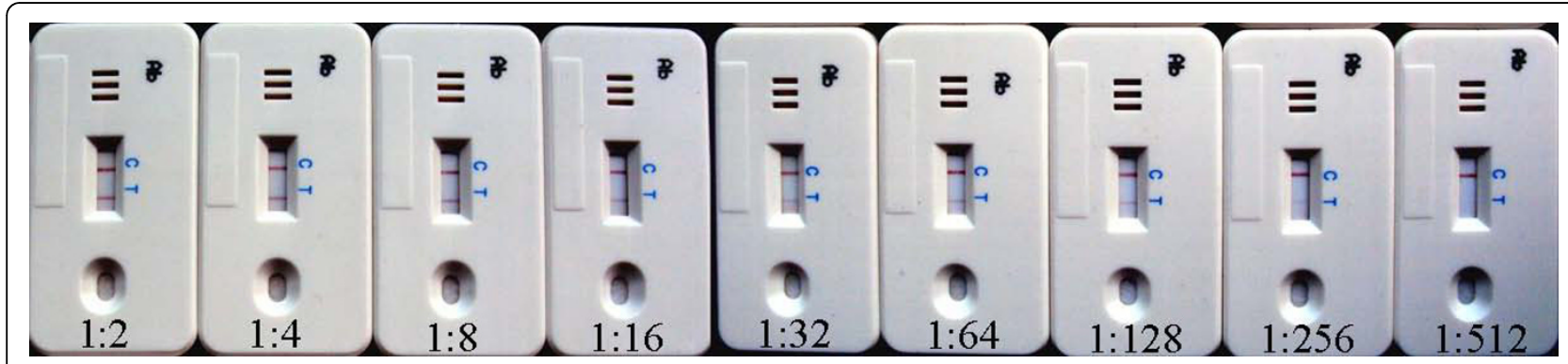

Figure 3 Sensitivity of the immunochromatographic strip (ICS) test. Reference positive sera against DEV at different dilutions (from 1:2 to 1:512) were used to analyze DEV-specific antibodies by the ICS test. Data are presented as the mean dilution of each serum at a single assay. 
Table 1 Comparison of the percentages of anti-DEV positive sera among ICS, ELISA and $\mathrm{NT}^{\mathrm{a}}$

\begin{tabular}{llll}
\hline & Method & \\
\cline { 2 - 4 } & ICS & ELISA & NT \\
\hline Positive serum & 41 & 47 & 25 \\
Negative serum & 69 & 63 & 85 \\
Ratio of positive $^{\text {b }}$ & $37.27 \%$ & $42.73 \%$ & $22.73 \%$ \\
\hline
\end{tabular}

a The total of 110 duck sera samples were simultaneously analyzed by the ICS, ELISA and NT assays.

${ }^{b}$ The percentiles of anti-DEV positive sera were analyzed by the Chi-square test.

however, the ELISA using the whole virus as coating antigen to detect antibodies usually leads to false positives, owing to the complex components of the purified virus, which may incorporate various host cell proteins. Furthermore, ELISA usually requires laboratory operation, skilled technicians, a special instrument, and takes about $3.5 \mathrm{~h}$ to complete the measurement, making it difficult for use in the rapid and on-site detection of antiDEV antibodies. The NT using duck embryo fibroblasts [7], one of the gold standard tests, usually detects antibodies against DEV. This test is very specific, but it has lower sensitivity and commonly takes about 3-5 days to obtain results, and is not suitable for testing large quantities of serum samples. Other methods for detecting anti-DEV antibodies, such as agar gel precipitin test, Dot-ELISA assay, and passive hemagglutination assay [12], are either less sensitive and time-consuming assay, or require special equipments and complex procedures. Therefore, the development of this new, simple and powerful ICS test for the rapid and on-site detection of DEV-specific antibodies is significant.

In this paper, a simple and rapid ICS test based on recombinant UL51 protein has been successfully developed, which could rapidly detect duck IgG antibodies against the UL51 of DEV, both qualitatively and quantitatively, if using serially diluted duck serum, without cross-reaction with antibodies against other tested viruses. In comparison with the commercial standard assay, ELISA, the sensitivity of the ICS test was

Table 2 Comparison of consistency ratios among ICS, ELISA $^{a}$ and NT ${ }^{b}$

\begin{tabular}{lllll}
\hline & $\begin{array}{l}\text { ELISA } \\
\text { Positive }\end{array}$ & Negative & $\begin{array}{l}\text { NT } \\
\text { Positive }\end{array}$ & Negative \\
\hline ICS & & & & \\
Positive & 35 & 6 & 8 & 33 \\
Negative & 12 & 57 & 17 & 52 \\
\hline
\end{tabular}

${ }^{a}$ The consistency ratio of the positive number of ICS to the positive number of ELISA is $85.37 \%$ and that of the negative number of ICS to the negative number of ELISA is $82.61 \%$.

${ }^{b}$ The consistency ratio of the positive number of ICS to the positive number of NT is $19.51 \%$ and that of the negative number of ICS to the negative number of NT is $75.36 \%$. comparable to the highly sensitive ELISA. Simultaneously, compared with the gold standard assay, NT, the sensitivity of the ICS test was significantly higher than the NT. Unlike these commonly used assays, the ICS test for the detection of DEV-specific antibodies does not require any equipment or skilled technicians and can be conveniently performed on the duck farm by a duck farmer. Importantly, the detection of DEV-specific antibodies by the ICS test only takes about $15 \mathrm{~min}$, which is much faster than the time required for the ELISA and NT assays, and the results can be read directly by the naked eye. Therefore, the ICS test is a high specific and sensitive assay for the rapid and reproducible detection of DEV specific antibodies, which is easy to operate and low in cost. It could be adapted for on-site surveillance in duck flocks.

Outbreaks of DEV throughout the world have resulted in significant economic losses in the duck breeding industry. Effective vaccination to induce immune responses to DEV is expected to control the spread of DVE. Therefore, the epidemiological surveillance of DVE and vaccine-induced immune responses require a sensitive and specific assay that can be conveniently operated to rapidly detect antibodies against DEV. The ICS test has been shown to rapidly detect antibodies to DEV. Its application may economically benefit duck farmer by monitoring the antibody levels of vaccinated duck flocks, and investigating the epidemiology of DEV in unvaccinated duck flocks.

\section{Conclusions}

In summary, we successfully developed a simple and rapid ICS test for detecting DEV serum antibodies for the first time. Compared with the ELISA and NT, the ICS test was able to detect anti-DEV antibodies in naturally infected duck sera with high sensitivity and specificity. The ICS components, which are provided in a sealed package, require no refrigeration and are stable for 12 months. This ICS test is convenient, rapid and easy to perform, with no requirement of specialized equipment, reagent or technicians. Thus, it has great potential to be used for the serological surveillance of DEV infection in the field.

\section{Methods \\ Large-scale preparation and purification of the recombinant UL51 protein}

Strain and expression vector: A recombinant expression plasmid pET28a-UL51 was successfully constructed as described previously [19]. Then, the pET28a-UL51 plasmid was transformed into E. coli strain BL21 (DE3) (obtained from the Key Laboratory of Animal Disease and Human Health of Sichuan Province). The bacterial cells transformed with the pET28a-UL51 plasmid were 
grown in Luria-Bertaini (LB) agar medium containing 50 $\mu \mathrm{g} / \mathrm{mL}$ kanamycin, and were incubated overnight at $37^{\circ}$ C. $200 \mathrm{~mL} \mathrm{LB}$ medium containing $50 \mu \mathrm{g} / \mathrm{mL}$ kanamycin was inoculated with a freshly grown colony containing the pET28a-UL51 plasmid, and was incubated for $16 \mathrm{~h}$ at $37^{\circ} \mathrm{C}$ as the seed culture.

Fermentation: A twenty liter fermenter (B.Braun, BIOSTATRB, Germany) containing $10 \mathrm{~L}$ of LB medium containing $50 \mu \mathrm{g} / \mathrm{mL}$ kanamycin and $1 \mathrm{~mL}$ antifoam was inoculated with $2 \% \mathrm{v} / \mathrm{v}$ seed culture $(200 \mathrm{~mL}) .10 \mathrm{~L}$ fermentation culture was grown at $640 \mathrm{rpm}, 37^{\circ} \mathrm{C}, \mathrm{pH}$ 7.0 , and $50 \%$ dissolved oxygen (DO) for $2-3 \mathrm{~h}$, until bacterial cells reached the mid-log phase of growth $\left(\mathrm{A}_{550}\right.$ $\mathrm{nm}=0.5-1.0)$. Then the recombinant UL51 protein expression was induced by the addition of $0.4 \mathrm{mmol} / \mathrm{L}$ isopropyl-1-thio- $\beta$-D-galactoside (IPTG) for $3 \mathrm{~h}$ at the same conditions. $1 \mathrm{~mL}$ bacterial cultures was taken at 3 $\mathrm{h}$ after induction, and the induced bacterial cells were pelleted by centrifugation at $8,000 \mathrm{rpm}$ for $5 \mathrm{~min}$, resuspended in $50 \mu \mathrm{L}$ of $1 \times$ SDS loading buffer, boiled for 5 min, and analyzed by SDS-PAGE. Then large quantities of bacterial cells were harvested by centrifuging at 8,000 rpm for $10 \mathrm{~min}$ and stored at $-20^{\circ} \mathrm{C}$.

Purification and solution of inclusion bodies: The harvested bacterial cell paste $(50.6 \mathrm{~g})$ was resuspended thoroughly in $240 \mathrm{~mL}$ of TE buffer $(20 \mathrm{mmol} / \mathrm{L}$ Tris$\mathrm{HCl}, 5 \mathrm{mmol} / \mathrm{L}$ EDTA, $\mathrm{pH}$ 8.0). The suspension was sonicated for 30-spulses, at least ten times, at $1 \mathrm{~min}$ intervals, using a microtip (Branson Ultrasonic Corporation). The pellets of the inclusion bodies were collected by centrifugation at $10,000 \mathrm{rpm}$ for $10 \mathrm{~min}$ at $4^{\circ}$ $\mathrm{C}$, were resuspended in $120 \mathrm{~mL}$ washing buffer (10 $\mathrm{mmol} / \mathrm{L}$ PBS, $2 \mathrm{~mol} / \mathrm{L}$ urea, $1 \%$ TritonX-100 (v/v), pH 7.4) under constant stirring for $10 \mathrm{~min}$, then followed by centrifugation at $10,000 \mathrm{rpm}$ for $10 \mathrm{~min}$ at $4^{\circ} \mathrm{C}$, and the above steps repeated twice to release the trapped protein. Finally, the purified inclusion bodies were dissolved in denaturing buffer $(10 \mathrm{mmol} / \mathrm{L}$ PBS and 8 $\mathrm{mol} / \mathrm{L}$ urea, $\mathrm{pH}$ 7.4) for $1 \mathrm{~h}$ at $4^{\circ} \mathrm{C}$, and were analyzed by SDS-PAGE.

Renaturation of inclusion bodies: The inclusion bodies were dialyzed in different concentrations of urea buffer solution $(6 \mathrm{~mol} / \mathrm{L}, 4 \mathrm{~mol} / \mathrm{L}, 3 \mathrm{~mol} / \mathrm{L}, 2$ $\mathrm{mol} / \mathrm{L}, 1 \mathrm{~mol} / \mathrm{L}$ and $0 \mathrm{~mol} / \mathrm{L}$ urea in $10 \mathrm{mmol} / \mathrm{L} \mathrm{PBS}$, $\mathrm{pH}$ 7.4) to refold before determination of the protein content by the Bradford protein assay [28]. The fusion protein solution was adjusted to the concentration of 2 $\mathrm{mg} / \mathrm{mL}$, divided into small aliquots, and was analyzed by SDS-PAGE. Rabbit anti-DEV antiserum (obtained from our laboratory) and horseradish peroxidase (HRP)-labeled sheep anti-rabbit IgG were used as the first and second antibody, respectively, for western blotting. The remaining protein solution was stored at $-20^{\circ} \mathrm{C}$ for later use.

\section{Preparation and assembly of ICS}

An ICS test for detecting DEV-specific antibodies was developed. A sandwich immunoreaction was performed on the ICS $[16,29,30]$. Briefly, the ICS assembly consists of a sample pad, a conjugate pad, a nitrocellulose membrane, and an absorption pad. Both the recombinant UL51 protein conjugated with colloidal gold and the goat anti-rabbit IgG conjugated with colloidal gold (provided by Shanghai Goldbio Tech Co., Ltd) were sprayed onto a glass fiber pad. The pad was then dried at $37^{\circ} \mathrm{C}$ overnight. Purified recombinant UL51 protein, whose optimal concentration was determined as $2 \mathrm{mg} / \mathrm{mL}$, was micro-sprayed onto a nitrocellulose membrane at $1 \mu \mathrm{L} / \mathrm{cm}$ at a position that would become the capture test band $(\mathrm{T})$ of the completed strip. The purified rabbit IgG, whose optimal concentration was determined as $1 \mathrm{mg} / \mathrm{mL}$, was micro-sprayed onto the same nitrocellulose membrane at $1 \mu \mathrm{L} / \mathrm{cm}$ at a position that would become the control band $(\mathrm{C})$; the membrane was dried at $37^{\circ} \mathrm{C}$ overnight. The conjugate pad was cut into strips $5 \mathrm{~mm}$ long and $5 \mathrm{~mm}$ wide. The nitrocellulose membrane was sliced into strips $25 \mathrm{~mm}$ long and 5 $\mathrm{mm}$ wide. One end of the conjugate pad was attached to the sample pad and the other end overlapped the membrane. An absorption pad (cellulose membrane) was attached to the end of the membrane to remove excess reaction mixture. The sample pad, conjugate pad, immobilized nitrocellulose membrane, and absorption pad were glued together on a plastic backing plate $(60 \mathrm{~mm} \times 5$ $\mathrm{mm})$, as shown in Figure 4a. Each strip was housed in a plastic case that was then stored in a desiccated plastic bag (Shanghai Goldbio Tech Co., Ltd).

\section{Principle of ICS test}

The principle of the ICS test is based on the following theory. If the tested duck serum contains the antibody against DEV, the antibody will be absorbed from the sample pad, which will interact with the recombinant UL51 protein on the conjugate pad to form an antigenantibody complex. The complex will migrate into the nitrocellulose membrane by capillary action and, subsequently, react with the immobilized recombinant UL51 protein on the testing line $(\mathrm{T})$, generating a red band, the density of which will be in proportion to the concentration of antibody against DEV. Nonreactive goat anti-rabbit IgG on the conjugate pad will run over the test line, and then reacts with the rabbit IgG at the control line $(\mathrm{C})$ of the strip to form the second visible red band. Thus, after approximately $100 \mu \mathrm{L}$ of the duck serum specimen was added to the sample chamber and let stand for $15 \mathrm{~min}$, the results were considered positive (if the red band was present at both the test line and the control line) (Figure 4b), negative (if the red band appeared only at the control line) (Figure $4 \mathrm{~b}$ ), or invalid (if no red band developed at either lines or only one 


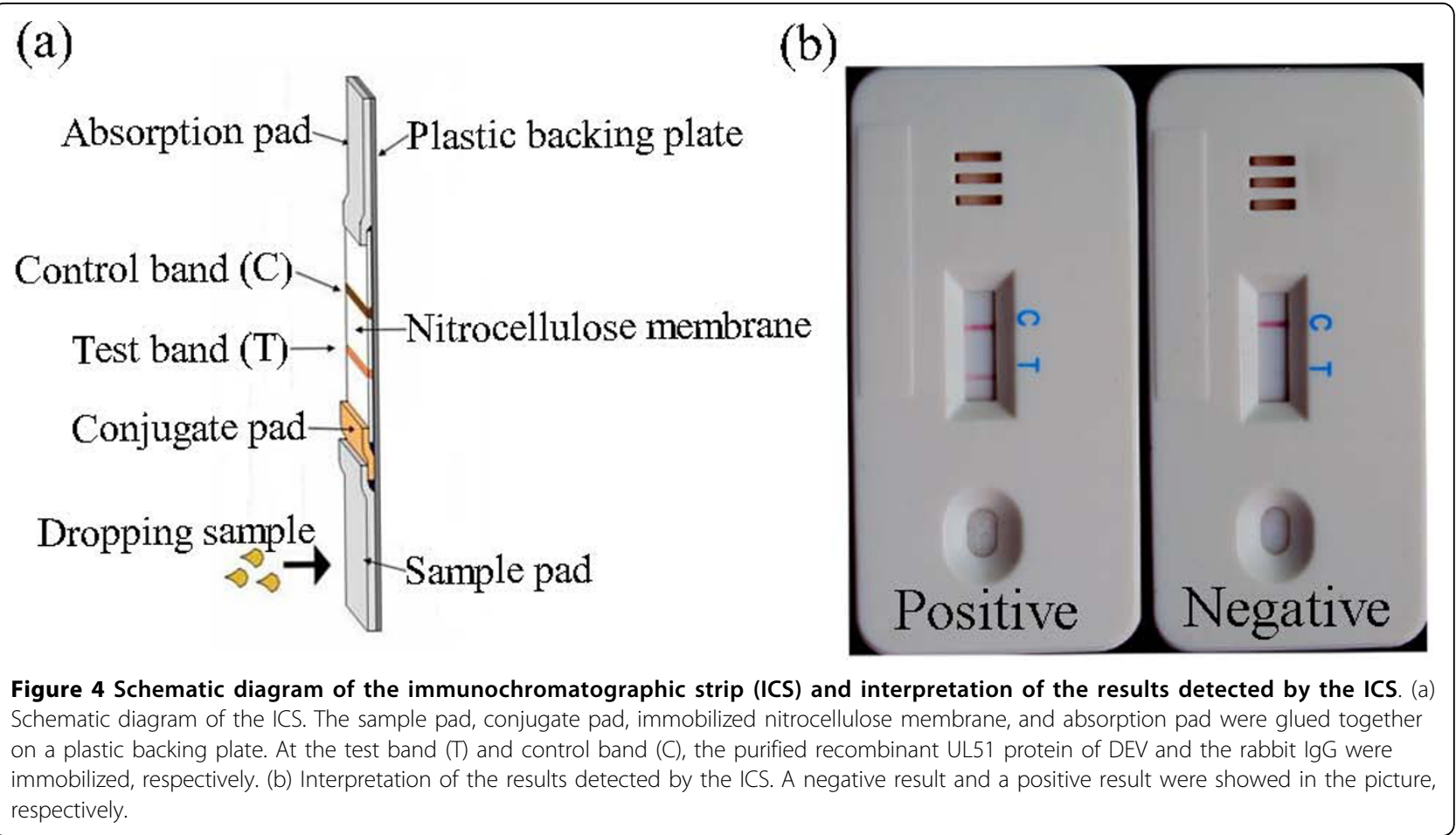

band appeared at the test line). Evaluation of the teststrip results can be performed with the naked eye and total assay time is less than $15 \mathrm{~min}$.

\section{Specificity, sensitivity and stability of the ICS test}

The specificity of the ICS test was evaluated with standard negative serum samples from 5 healthy ducks, 25 standard serum samples positive for non-DEV pathogens (the pathogens for Duck hepatitis virus (DHV), Riemerella anatipestifer (RA), Duck E. coli, Muscovy duck parvovirus (MPV), or Duck Influenza viruses (DIV)), 5 standard serum samples positive for DEV. All the standard serum samples were supplied by our laboratory.

The sensitivity of the ICS was tested with serially diluted anti-DEV serum. The standard serum sample was diluted 8 times with $10 \mathrm{mmol} / \mathrm{L}$ PBS from $1: 2$ to 1:512. The diluted sera were tested with this ICS. The same procedure was repeated three times with different operators.

The stability of the ICS was determined with the standard positive serum and the standard negative serum. At each sample time, 8 strips that had been respectively stored for 3, 6, 9, and 12 months at room temperature (about $25^{\circ} \mathrm{C}$ ), were tested.

\section{ELISA}

An ELISA for the detection IgG antibody against DEV in serum was performed as previously described $[10,9]$. In brief, the DEV CHv strain (obtained from our laboratory) virions abundantly propagated in duck embryo fibroblasts (DEF) was purified by differential velocity centrifugation and sucrose density gradient centrifugation. Round-bottomed 96 well polystyrene plates (Nunc MaxiSorp) were coated overnight with the prepared highly purified DEV virions $(100 \mu \mathrm{L} /$ well $)$ at $4{ }^{\circ} \mathrm{C}$ in a humidity chamber. The plates were washed three times with PBS$\mathrm{T}$ buffer $(10 \mathrm{mmol} / \mathrm{L}$ PBS containing $0.05 \%$ Tween-20), non-specific protein binding sites were blocked with blocking buffer $(10 \mathrm{mmol} / \mathrm{L}$ PBS containing $1 \%$ fetal calf serum) for $60 \mathrm{~min}$ at $37^{\circ} \mathrm{C}$, and the plates were then washed three further times with PBS-T buffer. A 10-fold dilution series of serum, diluted with PBS, were added and the plates incubated for $60 \mathrm{~min}$ at $25^{\circ} \mathrm{C}$ following by washing, $50 \mu \mathrm{L}$ of HRP-labeled goat anti-duck IgG (KPL) (1:4000 dilution with PBS containing $1 \%$ bovine serum albumin) was added. Following incubation for $60 \mathrm{~min}$ at $25^{\circ} \mathrm{C}$, the plates were washed and $100 \mu \mathrm{L} 3,3^{\prime}, 5,5^{\prime}$-etramethylbenzidine $(\mathrm{TMB})$ substrate solution (KPL) was added along with $0.01 \%$ of $\mathrm{H}_{2} \mathrm{O}_{2}$ in $0.05 \mathrm{~mol} / \mathrm{L}$ citric acid buffer (pH5.0). After $15 \mathrm{~min}$, the reaction was terminated by adding $50 \mu \mathrm{L}$ of $0.5 \mathrm{~mol} / \mathrm{L}$ sulfuric acid solution. The absorbance was read at $450 \mathrm{~nm}$ on a 96 -well plate reader (Model 460, Bio-Rad). The results were expressed as serum antibody titer defined as the $\log 10$ of the dilution that generated an optical density (OD) equal to two standard deviations (SD) above the mean background OD of negative control duck sera at $450 \mathrm{~nm}$. 
NT

The NT was performed as previously described $[7,8]$. Briefly, the serum was heated at $56^{\circ} \mathrm{C}$ for $30 \mathrm{~min}$ to inactivate complement and diluted by means of serial two-fold dilutions in MEM. Then, the diluted sera were equally mixed with a $200 \mathrm{TCID}_{50}$ dose of DEV CHv strain at $37^{\circ} \mathrm{C}$ for $1 \mathrm{~h}$. The mixtures were inoculated into the DEF cultured in 24-well plates (Corning Incorporated). The cytopathic effect (CPE) was observed, and the neutralizing antibody titer of the serum was calculated using the Reed-Muench formula.

\section{The analysis of 110 field serum samples}

Using the ICS, 110 sera that had been collected from several non-immune duck flocks in Sichuan province, were tested. They were also tested for antibody against DEV using the ELISA and NT following the above instructions.

\section{Statistical analysis}

The percentiles of anti-DEV positive sera were statistically analyzed by Chi-square test and a $\mathrm{P}$ value of $\leq 0.05$ was considered significantly.

\section{Acknowledgements}

The research were supported by grants from the National Natural Science Foundation of China (No.30771598), Changjiang Scholars and Innovative Research Team in University (PCSIRT0848), the earmarked fund for Modern Agro-industry Technology Research System (nycytx-45-12) and the Cultivation Fund of the Key Scientific and Technical Innovation Project, the Ministry of Education of China (No.706050).

\section{Author details}

${ }^{1}$ Avian Diseases Research Center, College of Veterinary Medicine of Sichuan Agricultural University, Ya'an, Sichuan, 625014, China. ${ }^{2}$ Key Laboratory of Animal Diseases and Human Health of Sichuan Province, Ya'an, Sichuan, 625014, China. ${ }^{3}$ Epizootic Diseases Institute of Sichuan Agricultural University, Ya'an, Sichuan, 625014, China.

\section{Authors' contributions}

CJS carried out most of the experiments and drafted the manuscript. ACC MSW, KFS, RYJ, TS, NZ, DKZ, QHL, YZ, and XYC helped in experiments and drafted the manuscript. All authors read and approved the final manuscript.

\section{Competing interests}

The authors declare that they have no competing interests.

Received: 23 June 2010 Accepted: 14 October 2010 Published: 14 October 2010

\section{References}

1. Sandhu TS, Metwally SA: Duck Virus Enteritis (Duck Plague). In Diseases of poultry. Edited by: Saif YM. Singapore: Blackwell Publishing; , 12 2008:384-393.

2. Baudet AE: Mortality in ducks in the Netherlands caused by a filterable virus. Fowl plague 1923, 50:455-459.

3. Huang YX: Study on duck plague-like disease. J South China Agric Univ 1959, 1:1-12.

4. Burgess EC, Ossa J, Yuill TM: Duck plague: a carrier state in waterfowl. Avian Dis 1979, 23:940-949.

5. Lin W, Lam KM, Clark WE: Active and Passive Immunization of Ducks against Duck Viral Enteritis. Avian Dis 1984, 28:968-977.
6. Islam MA, Samad MA, Rahman MB, Hossain MT, Akter S: Assessment of Immunologic Responses in Khaki Cambell Ducks Vaccinated Against Duck Plague. Int J Poult Sci 2005, 4:36-38.

7. Dardiri AH, Hess WR: The incidence of neutralizing antibodies to duck plague virus in serums from domestic ducks and wild waterfowl in the United States of America. Proc Annu Meet US Anim Health Assoc 1967, 71:225-237.

8. Wolf K, Burke CN, Quimby MC: Duck viral enteritis: microtiter plate isolation and neutralization test using the duck embryo fibroblast cell line. Avian Dis 1974, 18:427-434.

9. Qi X, Cheng A, Wang M, Yang X, Jia R, Chen X: Development of an indirect-ELISA kit for detection of antibodies against duck plague virus. Vet Sci Chin 2007, 37:690-694.

10. Yang X, Qi X, Cheng A, Wang M, Zhu D, Jia R, Chen X: Intestinal mucosal immune response in ducklings following oral immunisation with an attenuated Duck enteritis virus vaccine. Vet J 2009.

11. Qi X, Yang X, Cheng A, Wang M, Zhu D, Jia R, Luo Q, Chen X: Intestinal mucosal immune response against virulent duck enteritis virus infection in ducklings. Res Vet Sci 2009, 87:218-225.

12. Malmarugan S, Sulochana S: Comparison of dot-ELISA passive haemagglutination test for the detection of antibodies to duckplague. Indian Vet J 2002, 79:648-651.

13. Peng D, Hu S, Hua Y, Xiao Y, Li Z, Wang X, Bi D: Comparison of a new gold-immunochromatographic assay for the detection of antibodies against avian influenza virus with hemagglutination inhibition and agar gel immunodiffusion assays. Vet Immunol Immunopathol 2007, 117:17-25.

14. Mao X, Baloda M, Gurung AS, Lin Y, Liu G: Multiplex electrochemical immunoassay using gold nanoparticle probes and immunochromatographic strips. Electrochemistry Communications 2008, 10:1636-1640

15. Cui S, Chen C, Tong G: A simple and rapid immunochromatographic strip test for monitoring antibodies to H5 subtype Avian Influenza Virus. J Virol Methods 2008, 152:102-105.

16. Cui S, Zhou S, Chen C, Qi T, Zhang C, Oh J: A simple and rapid immunochromatographic strip test for detecting antibody to porcine reproductive and respiratory syndrome virus. J Virol Methods 2008, 152:38-42.

17. Kameyama K, Sakoda $Y$, Tamai K, Igarashi H, Tajima M, Mochizuki T, Namba Y, Kida H: Development of an immunochromatographic test kit for rapid detection of bovine viral diarrhea virus antigen. $J$ Virol Methods 2006, 138:140-146.

18. Tsuda Y, Sakoda Y, Sakabe S, Mochizuki T, Namba Y, Kida H: Development of an immunochromatographic kit for rapid diagnosis of $\mathrm{H} 5$ avian influenza virus infection. Microbiol Immunol 2007, 51:903-907.

19. Shen C, Cheng A, Wang M, Guo Y, Zhao L, Wen M, Xie W, Xin H, Zhu D: Identification and characterization of the duck enteritis virus UL51 gene. Arch Virol 2009, 154:1061-1069.

20. Shen C, Guo Y, Cheng A, Wang M, Zhou Y, Lin D, Xin H, Zhang N: Characterization of subcellular localization of duck enteritis virus UL51 protein. Virol J 2009, 6:92.

21. Li Y, Huang B, Ma X, Wu J, Li F, Ai W, Song M, Yang H: Molecular characterization of the genome of duck enteritis virus. Virology 2009, 391:151-161.

22. Klupp BG, Granzow H, Klopfleisch R, Fuchs W, Kopp M, Lenk M, Mettenleiter TC: Functional analysis of the pseudorabies virus UL51 protein. J Virol 2005, 79:3831-3840.

23. Nozawa N, Kawaguchi Y, Tanaka M, Kato A, Kato A, Kimura H, Nishiyama Y: Herpes simplex virus type 1 UL51 protein is involved in maturation and egress of virus particles. J Virol 2005, 79:6947-6956.

24. Koshizuka T, Kawaguchi Y, Nozawa N, Mori I, Nishiyama Y: Herpes simplex virus protein UL11 but not UL51 is associated with lipid rafts. Virus Genes 2007, 35:571-575.

25. Jia R, Cheng A, Wang M, Qi X, Zhu D, Ge H, Luo Q, Liu F, Guo Y, Chen X: Development and evaluation of an antigen-capture ELISA for detection of the UL24 antigen of the duck enteritis virus, based on a polyclonal antibody against the UL24 expression protein. J Virol Methods 2009, 161:38-43.

26. Guo Y, Cheng A, Wang M, Zhou Y: Purification of anatid herpesvirus 1 particles by tangential-flow ultrafiltration and sucrose gradient ultracentrifugation. J Virol Methods 2009, 161(1):1-6. 
27. Yang J, Hua Q, Chen H, Lv J, Qin Z, Jin M, Tao H, Zeng S, Ruan Z, Chen B, Zhou X: Development and evaluation of an immunochromatographic strip for the detection of serum antibodies against bluetongue virus. $J$ Virol Methods 2010, 163:68-73.

28. Bradford MM: A rapid and sensitive method for the quantitation of microgram quantities of protein utilizing the principle of protein-dye binding. Anal Biochem 1976, 72:248-254.

29. Tanaka R, Yuhi T, Nagatani N, Endo T, Kerman K, Takamura Y, Tamiya E: A novel enhancement assay for immunochromatographic test strips using gold nanoparticles. Anal Bioanal Chem 2006, 385:1414-1420.

30. Liu G, Lin YY, Wang J, Wu H, Wai CM, Lin Y: Disposable electrochemical immunosensor diagnosis device based on nanoparticle probe and immunochromatographic strip. Anal Chem 2007, 79:7644-7653.

doi:10.1186/1743-422X-7-268

Cite this article as: Shen et al:: Development and evaluation of an immunochromatographic strip test based on the recombinant UL51 protein for detecting antibody against duck enteritis virus. Virology Journal 2010 7:268.

\section{Submit your next manuscript to BioMed Central} and take full advantage of:

- Convenient online submission

- Thorough peer review

- No space constraints or color figure charges

- Immediate publication on acceptance

- Inclusion in PubMed, CAS, Scopus and Google Scholar

- Research which is freely available for redistribution

Submit your manuscript at www.biomedcentral.com/submit
C Biomed Central 